\title{
Struggles for Recognition: The Liberal International Order and the Merger of Its Discontents
}

\author{
Rebecca Adler-Nissen and Ayşe Zarakol
}

\begin{abstract}
The Liberal International Order (LIO) is currently being undermined not only by states such as Russia but also by voters in the West. We argue that both veins of discontent are driven by resentment toward the LIO's status hierarchy, rather than simply by economic grievances. Approaching discontent historically and sociologically, we show that there are two strains of recognition struggles against the LIO: one in the core of the West, driven by populist politicians and their voters, and one on the semiperiphery, fueled by competitively authoritarian governments and their supporters. At this particular moment in history, these struggles are digitally, ideologically, and organizationally interconnected in their criticism of LIO institutions, amplifying each other. The LIO is thus being hollowed out from within at a time when it is also facing some of its greatest external challenges.
\end{abstract}

At the end of the last century, the prevailing conviction was that globalization had guaranteed the triumph of Western-style democracies. There was confidence that the Liberal International Order (LIO) ${ }^{1}$ was here to stay even in the event of US decline because it appealed to individual rationality, promoted global progress and democracy through diplomacy, and brought economic benefits to its member states by facilitating trade, foreign direct investments, and more efficient supply chains. In the second half of the last decade, that optimism has been replaced by concern or even pessimism about the LIO's durability, with the growing realization that liberal institutions are challenged by voters in the West itself, where established parties have either been taken over by populist forces or have lost ground to them, or where anti-liberal policy agendas have found popular support through developments such as Brexit. At the same time, Russian President Vladimir Putin's imprisonment of opponents, Turkish President Recep Tayyip Erdoğan's assaults on journalists, Brazilian President Jair Messias Bolsonaro's targeting of universities,

1. The LIO is the combination of practices and visions of "open markets, international institutions, cooperative security, democratic community, progressive change, collective problem solving, shared sovereignty, [and] the rule of law." Ikenberry 2011, 2. We focus primarily on the LIO's political components (see the definition in the editors' introduction 2021). For debates on liberal order, see Goddard 2018; Ikenberry and Nexon 2019; Jahn 2018. 
US President Donald Trump's, Hungarian Prime Minister Viktor Mihály Orbán's, and Italian Deputy Prime Minister Matteo Salvini's attacks on immigrants all undermine international cooperation and regulation. ${ }^{2}$ With the recent COVID-19 pandemic, barriers between states have become even higher, and the LIO has few genuinely enthusiastic defenders left.

Much ink has been spilled to explain this seemingly abrupt erosion of support for the LIO. Some argue that voters supporting politicians like President Trump have legitimate economic grievances because of the unevenly distributed benefits of globalization, ${ }^{3}$ but that does not explain significant support for populist policies in economically higher strata of Western societies. ${ }^{4}$ Others blame the rot on Russia, and to a lesser extent on semiperipheral member states of the LIO-for example, Hungary, Poland, and Turkey-for fomenting disunity and openly flouting the rules, ${ }^{5}$ as well as for meddling in the politics of core liberal countries via lobbying firms, hacking, and other means, including troll farms. ${ }^{6}$ But even if the impact of such actions is not exaggerated, ${ }^{7}$ we do not yet have a good explanation for why these states have so easily turned their backs on an order that they once seemed eager to join, or for how their message appeals to voters in the West.

This article starts by observing that two distinct forms of opposition to the LIO are in fact working in tandem to undermine it from within. These are "populist" politicians and their voters in the core, and recently anti-liberal or illiberal governments on the semiperiphery (yet often technically inside). When we refer to the "core" or "center" in this article, we mean societies that feel a strong cultural ownership of both the label and the symbols associated with the term West. When we refer to the "semiperiphery," we mean states that could be classified as Western (or have been at times) but could also be classified as non-Western (or have been at times). ${ }^{8}$ Furthermore, we will argue, by drawing on theories of recognition, ${ }^{9}$ that the root causes of discontent with the LIO lie beyond pure economics, ${ }^{10}$ and are largely driven by dissatisfaction with it as a recognition order. The discontented are frustrated with their perceived positions in the recognition hierarchy ${ }^{11}$ created by the LIO. Furthermore, we argue that the degree to which the LIO was genuinely embraced has been overestimated, even within its founding member states. The

2. Mead 2011, 42.

3. See Inglehart and Norris 2016; Muis and Immerzeel 2017.

4. Mutz 2018.

5. Ikenberry 2018.

6. See, for example, Lanoszka 2016; Stukal et al. 2017.

7. See, for example, Brubaker 2017; Hacker 2006.

8. Not all such states are today members of the LIO's institutions, but many have been since the end of the Cold War.

9. See Adler-Nissen 2014a, 2014b; Adler-Nissen and Tsinovoi 2019; Goffman 1963; Hegel 1807; Zarakol 2011, 2018.

10. The political economy articles in this special issue also conclude that the social dimensions of grievance in world politics have been overlooked.

11. For overviews of the hierarchy literature see Bially Mattern and Zarakol 2016; Lake 2009; Zarakol 2017a, 2017b. 
perceived golden age of liberalism with widespread political and public support for multilateralism is a historical fiction. ${ }^{12}$ Continuous ambivalence toward the LIO has existed throughout, especially outside the core, where many viewed liberal institutions as furthering Western interests ${ }^{13}$ or as status clubs deliberately disadvantaging non-members. ${ }^{14}$ Put another way, many in the semiperiphery have perceived the LIO as merely a friendlier version of previous Western-centric and hierarchical international orders extending back to the nineteenth century colonial order. Even formal entry into the LIO fails to eradicate suspicions that the discourse of liberalism is simply a front for more explicit forms of domination. In the core, positive attitudes have seemed superficially more stable, but substantial demographic groups in the West have actually never fully bought into the concept of the LIO, seeing it as undermining their self-perceived rightfully dominant position in the world.

The international system's hierarchical nature also explains why recognition struggles manifest differently in the core and in the semiperiphery. The LIO promised to remove social and economic inequalities between the West and the non-West created by previous international orders, but never quite managed to achieve equality within its own order. States in the semiperiphery blame the LIO for perpetuating the modern international system's historical hierarchies, and they resent its failed promises of equality. By contrast, in the core, discontented groups blame the LIO (and its elites) for stating aspirations of equality, which they resent for undermining or failing to protect historical hierarchies privileging Western supremacy. The semiperiphery group challenges the LIO as a Western-centric hierarchy, best replaced by a non-Western alternative. The core group wants to retain Western supremacy by dismantling the LIO itself. Nevertheless, the end result is the same: as an obstacle to the high-stature recognition they feel entitled to, the LIO is the perceived enemy of both recognition struggles.

We provide an answer to the question posed by this special issue by approaching populism ${ }^{15}$ in the West and anti-liberalism in the non-West from a historically and sociologically informed theoretical perspective. We contend that the reason for our current predicament can be found within the social hierarchies of modern world politics, some created by the LIO itself and some predating the current order but nevertheless interfering with its workings. There is an irony in that after decades of assuming threats would come from outside the order, the LIO's real vulnerability lies within. The LIO is not being bested by a rival (yet) but rather is being hollowed out by recognition grievances at a time when challenges such as climate change and the COVID-19 pandemic make our need for a working international order more acute than ever. The field of international relations (IR) must pay more attention to the

12. See Acharya 2014, 2017; Barma, Ratner, and Weber 2013; Nye 2017.

13. See also Alter and Raustiala 2018.

14. See, for example, Naylor 2018; Suzuki 2017; Viola 2020; Zarakol 2011, 2013.

15. We follow Mudde's definition of populism as "an ideology that considers society ultimately separated into two homogeneous and antagonistic groups, 'the pure people' versus 'the corrupt elite' where politics should express the will of the people." Mudde 2004, 543. 
desire for recognition as a driver in political behavior, along with the ways that such a search intersects with material concerns.

Our argument develops in five sections. Building on social theory, the following section details our understanding of recognition as well as our diagnosis that a two-pronged intersectional struggle for recognition challenges the LIO. A primarily domestic challenge from its core increasingly fuses with a primarily international challenge originating at its frayed edges, or semiperiphery. Section two explores the discontent of various groups in the West; section three explores the historical roots of semiperipheral members' resentments. The fourth section discusses the merger between these two strains, highlighting structural and material drivers, providing examples of the points of connection as well as clarifying why some agents-for example, Russia-have been especially well placed within the international order to take advantage of such drivers. Our concluding section delivers our prognosis for the LIO and discusses the implications for IR theory.

\section{Theorizing the LIO as a Recognition Order with Its Discontents}

In IR scholarship, recognition is typically understood in a legalistic sense in which states are recognized as sovereign entities. In other fields, such as philosophy, however, recognition is seen as a vital human need to be known, understood, and affirmed. ${ }^{16}$ The struggle for recognition not only manifests as a desire to be acknowledged, but is also fundamental to identity development, whether as individuals, groups, or states. Misrecognition-understood as a gap between an individual or a group's desired identity and how that person or group experiences being seen by others-destabilizes self-identity. ${ }^{17}$ Recognition struggles are complicated by the fact that genuine recognition from others is almost impossible to attain; our interactions always involve a modicum of misrecognition. ${ }^{18}$ In that sense, the struggle for recognition is continuously ongoing and performed by all actors. However, struggles for recognition do not always become destabilizing to existing orders. ${ }^{19}$ Here we focus on recognition struggles that become politically salient; ${ }^{20}$ that is, when a multitude of diverse and ambiguous individual experiences are articulated into a public discourse of misrecognition. ${ }^{21}$ Our focus here is on subsets of actors who once had or

16. See Hegel 1807; Markell 2003; Taylor 1992.

17. Adler-Nissen and Tsinovoi 2019. For example, victims of racism and colonialism suffer by being stigmatized as inferior, but their resistance to this negative depiction is complicated by the fact that inferiority has been internalized and naturalized. Fanon 1952; see also Búzás 2021.

18. See the 2018 special issue of Review of International Studies on misrecognition.

19. Many recognition struggles are status-quo oriented as states and their representatives act in tune with their standing, thereby reinforcing existing international pecking orders. Pouliot 2016.

20. How and which experiences are mobilized cannot be fully answered within the confines of this article. There may be parallels to the literature on revolutions and social movements. See, for example, Lawson 2019.

21. Adler-Nissen and Tsinovoi 2019. 
who tell themselves that they once had some standing, and now feel misrecognized particularly because of a loss of stature, real or imagined, in the recent or distant past. Such actors aim to restore hierarchies that elevate them to the high status they believe they are entitled to.

There is a well-established literature extending recognition theory to group rights, especially in the context of multiculturalism. ${ }^{22}$ Scholars argue that group identities need recognition too and can suffer from its absence. ${ }^{23}$ More recently in IR, an emerging literature argues for an understanding of state recognition beyond de jure sovereignty, ${ }^{24}$ finding that gaining legal sovereignty does not necessarily meet states' needs for recognition and that absence of recognition drives states to engage in status contests. Some draw an analogy between individuals and states in order to make this argument; ${ }^{25}$ others argue that states' quests for recognition are historically contingent, and that the modern state in particular must care about external recognition because it is domestically tasked with solving its citizens' recognition problems. ${ }^{26}$ International status competitions become a means for states to simulate a solution; if states rank high in international hierarchies, their citizens feel relatively recognized even if their individual situations are not ideal. ${ }^{27}$ Although material achievement facilitates a rise in international hierarchies, such achievement does not always guarantee recognition. When social recognition, expressed in social and symbolic markers of status, fails to match the acquired material state, the result is "status inconsistency," which breeds resentment. These observations are not specific to the LIO, and are generally applicable to any international order. Furthermore, like any order, the LIO also recognizes some actors more than others.

What makes the LIO different from previous orders is that, at least rhetorically, it disavows hierarchy, especially in terms of recognition. And precisely because it puts such emphasis on politics being based on notions of equality, rights, and rationality, the LIO is seen as hypocritical by those who are discontented with it. Such resentment stems partly from the LIO's failure to acknowledge the significance of some of the historical hierarchies it has inherited and partly from-despite its emphasis on progress-its failure to level others. ${ }^{28}$ Many semiperipheral (and non-Western) states that previously lost their historical stature vis-à-vis the core, continue to feel

22. See Fraser and Honneth 2003; Honneth 2001; Taylor 1992.

23. See Gutmann 2003; Taylor 1992.

24. See, for example, Aalberts 2018; Agne et al. 2013; Bartelson 2013; Epstein, Lindemann, and Sending 2018; Friedrichs 2016; Gallagher 2018; Holm and Sending 2018; Kinnvall and Svensson 2018; Lebow 2008; Lindemann 2013; Lindemann and Ringmar 2014; Reus-Smit 2013, 2017; Ringmar 2002, 2014; Strömbom 2014; Wendt 1999; Wolf 2011.

25. Ringmar 2014.

26. Zarakol 2018. Others focus on struggles for the mutal recognition of norms, which does not necessarily involve status or attempts to fit into an order, for example, Wiener 2018. For more on status, see Ward 2017 and Wohlforth et al. 2017.

27. Smith and Jarrko 1998.

28. A common criticism of liberalism in and outside of academia is its apparent amnesia about the degree to which it benefited and continues to benefit from realpolitik and Western imperialism. See Acharya 2018; Hobson and Sharman 2005; Mann 2007. 
misrecognized within the LIO, resenting it for its lack of progress. Concurrently, to the extent that the LIO has made progress toward equal recognition, this has come at the expense of certain Western demographic groups once privileged in the twentieth century, ${ }^{29}$ so those groups within the core resent the LIO for its progress. This is why the LIO is currently undermined from within, both domestically and internationally. Frustrated authoritarian and quasiauthoritarian regimes in the semiperiphery, and status-losing groups in the core, find common cause in one enemy: the cosmopolitan liberal elite that had promised material and symbolic equality with the LIO. ${ }^{30}$ On both sides, the LIO is seen as an obstacle to the creation of alternative order(s) that would recognize the high stature demanded by the discontented.

\section{The Center Cannot Hold: Discontent in the Core}

In the center, the backlash against the LIO is driven by communities that were previously catered to by political parties, domestic welfare, and solidarity mechanisms, but that are now feeling misrecognized. Some members of majoritarian racial or national groups feel increasingly threatened by immigration, the domestic extensions of civil rights, the growing recognition of previously "out-groups," the relative loss of their economic power, and the projected future loss of international stature for the West. ${ }^{31}$ They blame the LIO for all of these developments. ${ }^{32}$ Indeed, as Drolet and Williams explain, the New Right project "while diverse, has significant transnational linkages and affinities, and has questions of international politics at the heart of many of its most important elements." 33

As the distance between these core constituencies and domestic political elites grows, they increasingly disavow the LIO as a "bureaucracy" that did not exist when "times were better" and when they were symbolically privileged. ${ }^{34}$ This is exactly the sense of misrecognition at play when, for example, Brexit voters long for British exceptionalism and domination, rooted in a nostalgic view of British imperialist history. ${ }^{35}$ Ironically, because these groups are found in core states whose governments created and sustained the LIO, they are often conflated by outsiders with the proprietors of the LIO. In reality, these voters suspect the LIO of

\section{Kimmel 2017.}

30. Some populists explicitly address the LIO, whereas others use different regional and national proxies (for example, the EU, disloyal national elites with powerful international networks).

31. Rathbun et al. 2016.

32. There is widespread evidence from surveys that populist leaders and citizens in developed democracies blame international organizations such as the World Trade Organization (WTO), the International Monetary Fund (IMF), or the EU for policy outcomes, sometimes exonerating national politicians: for example, see Alcañiz and Hellwig 2011; Hobolt and Tilley 2014. National decision makers also play the blame game, gaining in domestic popularity if criticized by international organizations for, as an example, democratic backsliding, Schlipphak and Treib 2017.

33. Drolet and Williams 2018.

34. For example, as the "American heartland," "real Americans"; see Gest, Reny, and Mayer 2017.

35. Bhambra 2017. 
undermining the dominant position of their nation—and of the West more generallywithin international hierarchies.

The making of the LIO was largely an elite project, ${ }^{36}$ possible because of a "permissive consensus": the idea that the public does not have clearly defined preferences regarding foreign policy. ${ }^{37}$ As long as governments and experts stay within a "zone of acquiescence," they can engage in a range of foreign policy decisions. ${ }^{38}$ Although there was a rich debate about the importance of domestic politics for the success of new liberal institutions, ${ }^{39}$ and some insisted on the importance of broad-based support, ${ }^{40}$ many diplomats (and scholars) in the early years after World War II considered ordinary people to be uninterested in or incapable of forming opinions about foreign policy. This was partly reflected in the self-understanding of acquiescent groups that did not, at least not in the first decades of the liberal international project, object to its creation. Instead, polls from the 1940s and 1950s often show majorities in the West answering "don't know" or "no opinion" when questioned about the LIO's institutions. ${ }^{41}$ Official Gallup commentary on these polls notes that the unwillingness to answer questions about international affairs was "natural," given that these people were workers, farmers, or homemakers. ${ }^{42}$

Western working classes focused on climbing the social ladder, emulating the taste of the upper classes, acquiring material and symbolic goods from cars to education, ${ }^{43}$ and engaging in strategies not unlike those adopted by many non-Western states in the twentieth century, as we discuss in the next section. While prosperity grew, most people had "a sense of their place," 44 with strong class identities along with attachment to the nation-state. This hierarchical context forms part of the domestic landscape in which Western elites engaged in the construction of ambitious liberal institutions including the United Nations (UN), the North Atlantic Treaty Alliance (NATO), and the European Communities. In the United States, bipartisan cooperation increased during World War II, and consolidated ${ }^{45}$ during the Cold War with the perception of the common Soviet threat. ${ }^{46}$ Public opinion did not feature much in elite policy calculations until the Vietnam War. ${ }^{47}$ In Europe, the expectation was that "permissive support" would, as material gains from increased trade and

36. Colgan and Keohane 2017. See also Martin 2000.

37. Hooghe and Marks 2009, 5.

38. Daddow 2012; Lindberg and Scheingold 1970.

39. See Martin and Simmons 1998.

40. Haas 1970.

41. In 1949, in a Gallup survey of public satisfaction with the United Nations, 40 percent of the Dutch, 39 percent of Canadians, and 25 percent of Americans answered, "don't know" or "no opinion," in contrast to most surveys of today, in which only between 5 and 10 percent feel unable to answer similar questions.

42. For example, Gallup 1956, 1958.

43. Gartman 2004.

44. As Goffman 1956 put it.

45. See Wittkopf 1990.

46. Kupchan and Trubowitz 2007.

47. Since then, foreign policy has become the subject of an unprecedented level of partisan and ideological dispute." Wittkopf 1990, xvii. 
cooperation became apparent to the voter, lead to affective support. ${ }^{48}$ This was partly because these groups felt recognized as "the owners" of their nation-states. They may not have had a lot of say in these elite projects, but politicians symbolically and rhetorically catered to them. Today, by contrast, anxiety among those who see themselves as losers is grounded in deep discontent with politics ${ }^{49}$ This feeling of abandonment was compounded by the global financial crisis of 2007-2008 and the way that it was managed by the political establishment. Increasingly declining trust in authorities found a voice in national elections, especially regarding single-issue votes and in the digital environment. ${ }^{50}$ Such empowerment of previously more privileged and now frustrated non-elite groups is an important ingredient in the challenge to the LIO from the center.

Although economic issues have played a crucial role in the emergence of populist parties in the West and the end of the "permissive consensus," contemporary articulations of such grievances are also driven by recognition demands. Cross-national survey data from twenty "developed" democracies demonstrate that populists care significantly more about recognition than about redistribution. ${ }^{51}$ Indeed, many lower-income white voters supported President Trump because he ran on a nativist, anti-internationalist platform that appealed to them. ${ }^{52}$ These voter segments feel stigmatized $^{53}$ by views faulting individuals for their absence of success in education, housing, or job attainment. They also feel betrayed by the increased recognition that they think immigrants and/or minority groups receive. Representative panel data show that voting for Trump can be better explained by perceived threats to American global dominance and the rise of a majority-minority America-issues that threaten white Americans' sense of dominant group status-rather than by economic hardship. ${ }^{54}$ Indeed, not all populist voters are in lower income brackets. Anxiety about the West's loss of stature vis-à-vis the rest of the world transcends such class lines.

The populist coping strategy successfully mobilizes such anxieties and grievances into a positive social identity centered on the idea of representing the "real people" who are not adequately recognized by the liberal elite. ${ }^{55}$ Populist parties and politicians in the core of the LIO represent a variety of population segments and may differ in ideological programs, ranging through anti-immigration, anti-globalism, anti-Semitism, ultranationalism, and anti-capitalism, and, in Europe, antiAmericanism and Euro-scepticism to secession. Yet they all share a sense of their

48. Lindberg and Scheingold 1970.

49. Hochschild 2016.

50. See Pepinsky 2017, 11.

51. See Cramer 2016; Gidron and Hall 2017; Goodwin and Heath 2016.

52. Carnes and Lupu quoted in Pepinsky 2017, 10.

53. Stigmatization differs from simple discrimination in that a crucial component of stigma is its internalization by the stigmatized actor. Goffman 1963. See also Adler-Nissen 2014a, 2014b; Zarakol 2010, 2011, 2014.

54. Mutz 2018.

55. See De Vries and Edwards 2009; Rooduijn, Van Der Brug, and De Lange 2016. 
identity being threatened by liberal internationalism, and display anger against, for example, global markets, open borders, international regulation, and representative democracy. ${ }^{56}$ The populist backlash against the LIO is further fueled by how established parties and elites deal with challenges to their positions. In countries such as France, Germany, the Netherlands, Italy, Austria, and Sweden, the establishment's use of terms such as "pariah" may ultimately have reinforced the extremists' populist appeal. $^{57}$

To sum up, populism in the West is embedded in feelings of vulnerability and nostalgia $^{58}$ that are increasingly expressed in the form of anti-internationalism rather than through traditional left/right party politics. ${ }^{59}$ As strong positive class identities have atrophied, populism has become a viable coping mechanism for diverse groups sharing a sense of marginalization and misrecognition, targeting domestic political elites as out of touch, ${ }^{60}$ and rejecting international institutions in favor of nationalist retrenchment.

\section{The Widening Gyre: Discontent in the Semiperiphery}

IR scholarship generally attributes the LIO's appeal to semiperipheral and nonWestern states to one or a combination of the following: US investment and commitment, the post-World War II hegemony, ${ }^{61}$ the strength of its institutions and rules, ${ }^{62}$ the rationality of its economic incentives, ${ }^{63}$ the persuasiveness of its normative model and norm entrepreneurs, ${ }^{64}$ or the cooperative-security practices of the order. ${ }^{65}$ However, as critical scholarship has long argued ${ }^{66}$ liberalism also rests on historical (social, economic, and political) hierarchical relationships between the West and the non-West, without which it could not have come into being in the first place. ${ }^{67}$ For this reason, it cannot be assumed that semiperipheral (or non-Western) countries have joined (or rejected) the LIO for entirely "rational" reasons; they have done so because many saw (and still see) the LIO as yet another Western status club privileging its members, with membership offering a way to rise within the international hierarchies of the modern order.

56. Support for the LIO relates to the cleavage around Green/Alternative/Libertarian versus Traditional/ Authoritarian/Nationalist (GAL/TAN issues). Hooghe, Marks, and Wilson 2002.

57. Ellinas 2010.

58. See McDermott and Hatemi 2018; Spruyt, Keppens, and Van Droogenbroeck 2016.

59. The ideology of the old extreme right (which was anti-Semitic and radically antidemocratic) was rendered largely impotent in the West by the outcome of World War II. However, the extreme nationalist right is now sufficiently freed from shame to become politically potent. Rydgren 2005.

60. Pew Research Center 2017.

61. See Ikenberry 2001, 2011; Lake 1999; Nye 2017.

62. See Ikenberry 2018; Keohane 1984; Lake 2010; Pevehouse 2002; Simmons 2009.

63. See Eichengreen and Leblang 2008; Marinov and Goemans 2013.

64. See Finnemore and Sikkink 1998; Keck and Sikkink 1998.

65. Adler 2008 .

66. See, for example, Bell 2016; Morefield 2005, 2014.

67. Social hierarchies include racial, religious, cultural, national, and other identity-based hierarchies. 
The nineteenth century was pivotal in the creation of the modern international order $^{68}$ because for the first time economic indicators in "the West" manifestly surpassed those of Asia. ${ }^{69}$ Equally important, however, was the emergence during the long nineteenth century of a particular social relationship between the West and the rest of the international system, a relationship that would characterize international relations for the next century and beyond. ${ }^{70}$ "The West" came to be seen as the center of the world; its standards, from political to cultural, came to define what was seen as "normal," "11 shaping expectations of how international actors should behave (internally and externally). Those falling short of these expectations were stigmatized ${ }^{72}$ initially formally via the "Standard of Civilization," 73 which deprived states not considered "civilized" of equal legal recognition, and later in the twentieth century through more informal hierarchies such as modern versus traditional or First World versus Third World. This can be thought of as an "establishedoutsider" relationship: those who are "established" or early arrivers in a social setting have the power to set norms, and they look down on those who are "outsiders" or latecomers as being anomic, even if material differences between the two groups are insignificant. ${ }^{74}$ Social power allows differences to grow and/or to be reproduced over time. ${ }^{75}$ Being considered inferior to actors who define what is "normal" has significant material consequences as well. In the nineteenth century, for example, nonWestern states, even when independent, had lower legal standing and therefore fewer economic protections than European states and their former colonies settled by whites. ${ }^{76}$

Actors ranking lower in the social hierarchy of international politics are thus driven to overcome their stigma(s). ${ }^{77}$ The twentieth century offers examples of two stigmamanagement strategies. ${ }^{78} \mathrm{~A}$ few countries attempted to embrace their stigmatization by the core, wearing it as a badge of honor. The Soviet Union was the most high-profile example of a stigmatized state attempting to create its own normative/ ideological universe and gain recognition from the leadership of other similarly

68. Buzan and Lawson 2015.

69. See Osterhammel 2015; Pomeranz 2009.

70. See Mazower 2013; Morefield 2005.

71. See Manela 2007; Zarakol 2011.

72. See note 51 .

73. See Gong 1984; Towns 2010.

74. See Elias and Scotson 1965; Zarakol 2011.

75. The influence of social hierarchies in modern world politics is also confirmed by the English School. See Dunne and Reus-Smit 2017 and postcolonial scholarship; Keene 2002. See Barkawi and Laffey 2006; Bilgin and Morton 2002.

76. This did not end in the nineteenth century. For example, Manela 2007 has shown how India, China, Egypt, and Korea sought in vain to activate President Woodrow Wilson's rhetoric of national self-determination in their fights for independence, leaving a legacy of disappointment toward liberal internationalism.

77. See Adler-Nissen 2014a, 2014b; Zarakol 2011, 2014.

78. See Adler-Nissen 2014b; Naylor 2018; Suzuki 2017; Towns and Rumelili 2017; Zarakol 2011. 
situated states. ${ }^{79}$ However, even within its own sphere of influence, the Soviet Union never managed to overturn the primary narrative underwriting the social hierarchy of the modern international order; that is, the notion that the rest of world had to "catch up" with the West. By contrast, many more semiperipheral ${ }^{80}$ and non-Western states attempted to move up the international system's social hierarchy by "correcting" their stigmatizing attributes and by joining the status clubs of the West; that is, by assimilating into the "Western order." The late nineteenth and early twentieth centuries show many such states adopting "Western" norms, from seemingly trivial matters such as dress codes to more serious ones such as legal codes, ${ }^{81}$ as well as signing treaties and joining Western organizations for status-related reasons. ${ }^{82}$ Most importantly for the present discussion, we also see some of this same pattern after the end of the Cold War, when Central and Eastern European states joined the LIO. ${ }^{83}$ The Soviet Union could not sustain the parallel recognition hierarchy it had created, and its failure only reinforced (at least in the 1990s) the notion that the West was both the center and the future of world politics. The choice for the semiperiphery especially was between being recognized as Western or as "developing."

The post-World War II and the post-Cold War expansion of the LIO must be understood against this historical background. The LIO's attraction for semiperipheral (and non-Western) actors was not merely because of the material benefits offered but also because of issues of recognition and belonging. To attribute the LIO's creation primarily to US power, the persuasiveness of its elites, economic incentives, or the intrinsic appeal of its norms misses a primary reason many countries joined it, ${ }^{84}$ which was that they saw it as the inner core of the international system, a status club conveying special privileges and increased recognition. ${ }^{85}$ The choice involved not only the substantive merits of this order but also a desired identity label: "Western" or "First World" or "developed" versus its undesirable corollaries. ${ }^{86}$ The new entrants were not necessarily persuaded by the substantive arguments. Because the appeal of LIO for many ${ }^{87}$ was primarily about recognition and acceptance, joining did not require internalization of or acquiescence to liberal norms or rules. Without substantive persuasion, the resentment at having to perform those norms festered beneath the surface within certain segments of these societies, ${ }^{88}$

79. The Non-Aligned Movement, as well as China's attempts in Africa and elsewhere during the Cold War, fall under this heading. See, for example, Suzuki 2017.

80. Another way of thinking about this is that the semiperiphery is constituted by countries that have seriously exercised this strategy.

81. Note that this is different from being forced to adopt such rules under colonial administration.

82. See Anno 2018; Bull and Watson 1984; Checkel 2001.

83. See Krastev and Holmes 2019; Zaborowski 2006.

84. Holsti 1992, 439.

85. Aydın-Düzgit 2018; Mälksoo 2009, 2010; Rumelili 2008; Subotic 2011; Zarakol 2011.

86 . It should be noted that "liberalism" is almost a dirty word in many societies outside of the centre of the LIO. Hendrickson 2018.

87. And especially liminal actors in Eastern Europe and elsewhere whose belonging was in question.

88. Zarakol 2014, but compare Búzás 2018. 
which was made more acute when nominal acceptance into the LIO club failed to deliver the desired levels of recognition. ${ }^{89}$

It is also important to note that although resentments toward Western-centric hierarchies predate the LIO, the success of the LIO itself has ironically played a significant role across semiperipheral states in the rise of governments more representative of the resentful, anti-Western segments of those societies. First, especially from the 1980s and 1990s onwards, the norms of political and economic liberalization helped dismantle twentieth-century modernizing regimes of any ideology, thus opening up electoral competition, which generated political leaders more dependent on mass support. ${ }^{90}$ Although they were pro-LIO and/or pro-democracy in opposition, once in power, many of these leaders consolidated their positions by channeling resentments against the LIO, sometimes even by invoking conspiracy theories, ${ }^{91}$ and by "standing up" to the Western dominance that their domestic constituencies view as having treated them unfairly, for the historical reasons we reviewed. Second, global gains made under the LIO outside of the Western core economically empowered these groups in the semiperiphery. Finally, the unequal effects of the 2007-2008 global financial crisis and the investment channeled to "emerging markets" after $2008^{92}$ made such governments seem more successful and these countries seem more economically successful than they actually were, further emboldening their governments' active roles in international politics, which undermined the LIO from within. ${ }^{93}$

\section{Things Fall Apart: How the Merger of Discontents Hollows out the LIO from Within}

As previous sections made clear, discontented actors in the center and semiperiphery are unhappy with the LIO as an order of recognition, but for seemingly opposite reasons. Whereas the former thinks the LIO has undermined Western supremacy, the latter sees it yet as another manifestation of Western supremacy. Although their motivations for undermining the LIO and their plans for the aftermath are divergent, currently these two strains are reinforcing each other, creating a challenge to the LIO that is more than the sum of its parts.

89. Emulation, the attempt to move up in the hierarchy by mimicking high-ranked actors, never quite garners the desired recognition for the assimilating actor. The "established" cannot afford to have all emulating outsiders join their ranks for fear of losing their own status. At the very least there is resistance, as we discussed. Informal hierarchy even among formally equal members is thus propped up by shifting the criteria for emulation as soon as they are close to being reached. See Bauman 1991, 75-80; Bourdieu 1984; Zarakol 2011, 2014.

90. McCargo and Zarakol 2012; Zarakol 2013 discusses these developments in the cases of Turkey and Thailand, but the trajectory is generalizable.

91. Galston 2018.

92. Tooze 2018.

93. Zarakol 2019. The line in the heading here and the reference to the "widening gyre" in the previous heading come from "The Second Coming," the post World War I poem by William Butler Yeats. 
Three features of the present international system in particular make this interaction more potent. First, digital technology speeds up global dissemination of ideas and activism, and gives a voice to those who did not previously feel that they had one. Indeed, "the Internet produced electorates that were more plugged in to political debates and more independent-minded (although not necessarily better informed), which made them more critical of and less deferential toward traditional elites." 94 The discontented find mutual recognition via the global platforms of Facebook and Twitter. ${ }^{95}$ Digital disinformation, fake news, and information flooding tap into and give shape to the frustrations ${ }^{96}$ of a worldwide demographic of people who had never fully bought into the LIO.

Taking advantage of these frustrations, Russia waged a multifront disinformation campaign to affect the 2016 US election by supporting political extremist groups, "users dissatisfied with [the] social and economic situation" and those inclined to "use any opportunity to criticize Hillary and the rest (except Sanders and Trumpwe support them)." 97 The wider influence campaign included hacking attempts, information theft, and digital advertisements. Russia's Internet Research Agency (IRA) created social media accounts purporting to belong to ordinary American citizens. Facebook estimates that 126 million people were served content from the IRA during the election. Other studies have found IRA social media updates unintentionally embedded in traditional news media, serving as vox populi. ${ }^{98}$ In Germany, the most famous case of pro-Kremlin online disinformation was that of "Our Lisa," the supposed rape of a Russian-German girl in January 2016 by three "Muslim" or "Arab" men. Such disinformation triggered Russian-German demonstrations across Germany, leading to a spat between the German and Russian foreign ministers. ${ }^{99}$ In France, after Macron's initial surge in the presidential election in 2017, the Kremlin-sponsored platform Sputnik claimed that Macron was a closeted gay with "a very rich gay lobby" behind him, and his campaign was targeted by Russian hackers. ${ }^{100}$ These techniques are effective because they play on fears that elites serve and recognize other, previously "out" groups instead of the discontented.

Second, since the end of the Cold War, the global decline of ideologies and party politics associated with that period ${ }^{101}$ has lifted barriers to collaborations between groups and states previously in different camps, as is shown in the networks being forged among parties and leaders in the non-Western world. For example, "Islamist" Erdoğan's July 2018 presidential inauguration in Ankara, Turkey, was attended by Dmitry Medvedev, Venezuelan President Nicolás Maduro, Orbán, and

94. Mudde 2016, 28.

95. See Hjorth and Adler-Nissen 2019; Singer 2014.

96. See Adler and Drieschova 2021.

97. United States v. Internet Research Agency LLC, Grand Jury Indictment, 16 February 2018, US District Court, 14, 17.

98. Lukito et al. 2020.

99. Makarychev 2017.

100. Shekhovtsov 2018.

101. See Grossman and Sauger 2019; Rejai 2017. 
Serbian President Aleksandar Vučić, leaders running the gamut from supposed "far left" to "far right." 102 Similarly, Prime Minister Benjamin Netanyahu of Israel has strong ties with the illiberal leaders of Poland and Hungary, despite their frequent anti-Semitic rhetoric. ${ }^{103}$ Other examples include Bolsonaro's warm reception by Marine Le Pen, Matteo Salvini, and Steve Bannon; the cosy relations between Trump and Indian Prime Minister Narendra Damodardas Modi, Jared Kushner's ties with Muhammed bin Salman (MBS) of Saudi Arabia; and of course Vladimir Putin's "friendship" with populists throughout Europe as well as in the United States. In May 2019, early elections were called in Austria after a video emerged, showing the (nationalist) deputy chancellor offering public contracts to a woman he believed to be a Russian oligarch. These illiberal leaders are united by resentment of the LIO, as well as mutual financial interests and symbolic recognition, which sustains their networks. We are witnessing the emergence of unexpected connections among far-left groups, white nationalists, anti-Western Islamists, and Russian conspiracy theorists, which seem at first glance to have no ideological affinity. ${ }^{104}$ Although it may be too early to suggest a "nationalist international," 105 a globally interconnected vision is developing. ${ }^{106}$ This cross-fertilization creates ground-up pressures on Western politicians to change their discourses to match, while consolidating authoritarian and semiauthoritarian regimes elsewhere by seeming to corroborate their rhetoric. As Drolet and Williams note, this is sometimes the result of an effective strategy: "By stirring anxiety and mobilizing stigmas over foreign competition, unemployment, welfare and immigration, the [New Right] seeks to force mainstream political parties to revise their traditional positions to prevent an exodus of voters from the centre-right." 107

The third feature setting our era apart from seemingly comparable periods is that the main vulnerability is mostly generated by the actors formally within the LIO or participating in its various aspects. This is true both for the discontented groups in the West and also for the semiperipheral troublemakers. Although resentment toward Western domination is not new, what is novel is that current international challengers have in many ways been major beneficiaries of the LIO. Not only are their states members of LIO institutions and economic arrangements, but also many of the regimes expressing grievances against the LIO were actively supported by liberal elites during periods of power consolidation, and have been further buoyed by the economic developments of recent decades, as we discussed in the previous

102. Umut Uras, "Erdogan Sworn in as Turkey’s First Executive President," Al Jazeera, 9 July 2018. Available at <https:/www.aljazeera.com/news/2018/07/erdogan-set-sworn-turkey-executive-president180708165200590.html> Accessed 20 May 2019.

103. Kirkpatrick et al. 2018; Klapsis 2015; Laruelle 2018; Phillips 2018; Sternhell 2019.

104. See Makarychev 2017.

105. Abrahamsen et al. 2020.

106. For its ideological roots, ideational trajectories, and contemporary articulations, see Drolet and Williams 2018 as well as Tjalve 2020, for an account from citizen curators of digital disinformation, see Golovchenko, Hartmann, and Adler-Nissen 2018.

107. Drolet and Williams 2018, 306. 
section. ${ }^{108}$ This undercuts the prevailing assumption in the literature that material benefits would produce ideational convergence.

The particular timing of this merger is also related to a number of contingent factors, including the global financial crisis of 2007-2008, and the choices made by Putin's Russia as referred to previously. Russia is playing a larger than expected role in channeling the two strains of discontent together for a number of reasons. It is a frustrated former "great power," with attendant ambitions, a sense of entitlement regarding the international system, ${ }^{109}$ and grievances stemming from its loss of stature. ${ }^{110}$ But even more significantly, vis-à-vis the West, it is an actor able to play both sides of the West/non-West divide. ${ }^{111}$ In the Western core of the LIO, Russia occupies a special place in popular and political imagination, unmatched by other non-Western states, who are more overtly seen as outsiders, strangers, or aliens. For historical and identity-based reasons, however, Russia is viewed by at least some in the West ${ }^{112}$ more as a version of the Self ${ }^{113}$ that has gone wrong (or right, depending on the perspective). Historically, groups out of power in the West (nineteenth-century absolutists, twentieth-century communists, early twenty-first century right-wing reactionaries/white supremacists) have cast Russia as the alternative ideal to whatever dominates at home. Russia is therefore an "Other" for the West but not so much of an "Other" that it cannot be used by some as a model for the West. In reaching out to right-wing populists and white nationalists within the West via social media and other networks, ${ }^{114}$ Putin's Russia knowingly presents itself as a mythical "True West," the defender of Western civilization's white, Christian, and conservative values.

Italy's Far Right Northern League looks to Russia not only as an economic partner, but also as a model for "the protection of the family." 115 For populists in Britain, the Russian-promoted alternative may appear more attractive, not least because it promises a "return" to a sovereignty-based, Westphalian order with spheres of influence,

108. See also Lake, Martin and Risse 2021.

109. Gilpin 1981.

110. Schmitt 2020 .

111. See Tsygankov 2012; Zarakol 2011. The legacy also facilitates intervention in other countries' political affairs; see Way and Casey 2018.

112. For images of Russia in European political discourse, see, for example, Neumann 1995, 1998. Russia has played a similar role in US perceptions. In the nineteenth century, parallels were often drawn between the United States and Russia as being recently expansionist states coming onto the world stage (for example, between the Indian Removal Act and the Russo-Circassian War). During the twentieth century, despite its status as a threat, Russia/the Soviet Union continued to be idealized by an ideological minority as the future of the United States. To be clear, Russia has not been seen as an Other or as an enemy in the United States but rather simultaneously, because of its hybrid status, as a friend or an enemy, the past or the future, by different groups in the West.

113. Recent statements by the US State Department that in China, the United States will face its first nonCaucasian competitor and must therefore prepare for a clash of civilizations could also be read as affirming the insider-outsider status of Russia. See Gehrke 2019.

114. Another important component here is Russia's facility with social media. See Stukal et al. 2017.

115. The Northern League has also created a cultural exchange program, the Lombardy-Russia Cultural Association, receiving funding from the Russian propaganda outlet Sputnik. Klapsis 2015. 
for example, a world where Britain could regain its status outside the European Union. This ideological cross-fertilization is further fueled, as multiple reports have exposed, by the Kremlin directly financing the European far right. One of the first spectacular cases was the revelation in 2014 that the Front National had received 40 million euros from a Russian-controlled bank. ${ }^{116}$

At the same time, Russia's historical trajectory within the modern international system is much closer to that of other non-Western and semiperipheral states. Therefore, Russia has hybrid qualities and resentments specific to that hybridity that China, for example, does not have, but which other disruptive semiperipheral countries within or just on the fringes of the LIO share to some extent. Evidence also points to the Kremlin's financing of Hungary's far-right Jobbik since 2008, ${ }^{117}$ and its constant meddling in other parts of the semiperiphery, including in Turkey. ${ }^{118}$ The messages resonate for different reasons here than they do in the core. In reaching out to rightand left-wing populists within the Western center (and to authoritarian leaders of the semiperiphery), Russia performs as the country that can stand up to the LIO, either to save the West from it or to save others from the West. These claims work because they are in fact plausibly rooted in actual historical dynamics. No other country could pursue such a strategy, claiming simultaneously to be both anti-West and the salvation of the West, and nevertheless resonating with target audiences.

\section{The Prognosis for IR Theory and the LIO}

The reason that so many misunderstand what is happening to the LIO is ontological: they assume that the threat is either international or domestic. If the problem is international, then it is seen as an external challenge of information or hybrid warfare, ${ }^{119}$ eliciting a combined response of fact-checking and cyber security at home and military deterrence abroad. ${ }^{120}$ If the problem is seen as domestic, then it becomes about "audience costs," 121 or how ideology enters the bureaucracy of foreign policy, to be addressed by examining domestic processes of opinion formation and decision making. ${ }^{122}$ Yet, if the opposition to the LIO has started to structure new types of transnational networks among the discontented, who may be opposition groups in some places but state actors in others, the domestic/international distinction ceases to be as meaningful as it was in the last century.

Only by understanding these emerging transnational ideologies and networks, often facilitated by digital technology, can we begin to properly assess the LIO's

116. See Cooley and Nexon 2020 for an analysis of the transnational networks of illiberal parties receiving financial and moral support from, among others, Moscow.

117. Klapsis 2015.

118. Ünver 2019.

119. Pomarentsev 2015.

120. See Hoskins and Loughlin 2015.

121. Fearon 1994.

122. Gourevitch 2002. 
current malaise. In terms of data and methods, this has fundamental implications for what becomes relevant for IR scholarship: along with the study of national security and strategy, we should also examine social media interactions by ordinary citizens. Our argument also challenges the long-standing belief within political science that not only is the West a separate analytical category but also that developments within the Western core can be studied without reference to what is happening elsewhere in the world.

Our framework suggests a way of understanding that the seemingly disparate challenges that the LIO is facing stem from similar recognition logics. Those wishing to save the LIO tend to ignore the key problem: the LIO is not only a system of rules and institutions, it is also a recognition order, which inevitably produces discontented actors regardless of absolute gains. Arguably, the LIO has been better than previous Western-centric orders at addressing recognition problems outside of the core of the system. Indeed, its successes in this regard are partly to blame for some of the resistance it is facing from the center. Both governments and voters who wish to dispense with the LIO have actually benefited from the pluralism of this order as well as from its economic rewards. Furthermore, abandoning the LIO, as demanded by populist and anti-liberal challengers, would not remove the underlying recognition problems inherent in politics. Disruptive liminal states and populist Western voters are not advocating a more equal world, but rather their own hierarchical visions of the international (and domestic) order. Finally, it is important to remember that there are many more actors than just the proponents and the discontented of the LIO; the great majority outside the West perhaps fall on neither side while sympathizing with aspects of each camp. The fate of the LIO lies with this majority. Those who want to salvage the LIO need to ask what the LIO can do to recognize them, and to do so before alternatives emerge.

\section{References}

Aalberts, Tanja. 2018. Misrecognition in Legal Practice: The Aporia of the Family of Nations. Review of International Studies 44 (5):863-81.

Abrahamsen, Rita, Jean-François Drolet, Alexandra Gheciu, Karin Narita, Srdjan Vucetic, and Michael Williams. 2020. Confronting the International Political Sociology of the New Right. International Political Sociology 14 (1):94-107.

Acharya, Amitav. 2014. The End of American World Order. Polity.

Acharya, Amitav. 2017. After Liberal Hegemony: The Advent of a Multiplex World Order. Ethics and International Affairs 31 (3):271-85.

Acharya, Amitav. 2018. Constructing Global Order: Agency and Change in World Politics. Cambridge University Press.

Adler, Emanuel, and Alena Drieschova. 2021. The Epistemological Challenge of Truth Subversion to the Liberal International Order. International Organization 75 (2). < <ttps://doi.org/10.1017/ S0020818320000533>.

Adler, Emanuel. 2008. The Spread of Security Communities: Communities of Practice, Self-Restraint, and NATO's Post-Cold War Transformation. European Journal of International Relations 14 (2):195-230. 
Adler-Nissen, Rebecca. 2014a. Opting Out of the European Union: Diplomacy, Sovereignty and European Integration. Cambridge University Press.

Adler-Nissen, Rebecca. 2014b. Stigma Management in International Relations: Transgressive Identities, Norms, and Order in International Society. International Organization 68 (1):143-76.

Adler-Nissen, Rebecca, and Alexei Tsinovoi. 2019. International Misrecognition: The Politics of Humour and National Identity in Israel's Public Diplomacy. European Journal of International Relations 25 (1): $3-29$.

Agne, Hans, Jens Bartelson, Eva Erman, Thomas Lindemann, Benjamin Herborth, Oliver Kessler, Christine Chwaszcza, Mikulas Fabry, and Stephen D. Krasner. 2013. Symposium: The Politics of International Recognition. International Theory 5 (1):94-107.

Alcañiz, Isabella, and Timothy Hellwig. 2011. Who's to Blame? The Distribution of Responsibility in Developing Democracies. British Journal of Political Science 41 (2):389-411.

Alter, Karen J., and Kal Raustiala. 2018. The Rise of International Regime Complexity. Annual Review of Law and Social Science 14 (1):329-49.

Anno, Tadashi. 2018. National Identity and Great-Power Status in Russia and Japan: Non-Western Challengers to the Liberal International Order. Routledge.

Aydin-Düzgit, Senem. 2018. Foreign Policy and Identity Change: Analysing Perceptions of Europe Among the Turkish Public. Politics 38 (1):19-34.

Barkawi, Tarak, and Mark Laffey. 2006. The Postcolonial Moment in Security Studies. Review of International Studies 32 (2):329-52.

Barma, Naazneen, Ely Ratner, and Steven Weber. 2013. The Mythical Liberal Order. The National Interest 124 (March/April):56-67.

Bartelson, Jens. 2013. Three Concepts of Recognition. International Theory 5 (1):107-29.

Bauman, Zygmunt. 1991. Modernity and Ambivalence. Cornell University Press.

Bell, Duncan. 2016. Reordering the World: Essays on Liberalism and Empire. Princeton University Press.

Bhambra, Gurminder K. 2017. Locating Brexit in the Pragmatics of Race, Citizenship and Empire. In Brexit: Sociological Responses, edited by William Outhwaite, 91-100. Anthem Press.

Bially Mattern, Janice, and Ayşe Zarakol. 2016. Hierarchies in World Politics. International Organization 70 (3):623-54.

Bilgin, Pinar, and Adam Morton. 2002. Historicising Representations of "Failed States": Beyond the ColdWar Annexation of the Social Sciences? Third World Quarterly 23 (1):55-80.

Bourdieu, Pierre. 1984. Distinction: A Social Critique of the Judgment of Taste. Routledge.

Brubaker, Rogers. 2017. Why Populism? Theory and Society 46 (5):357-85.

Bull, Hedley, and Adam Watson, eds. 1984: The Expansion of International Society. Oxford University Press.

Buzan, Barry, and George Lawson. 2015. The Global Transformation: History, Modernity and the Making of International Relations. Cambridge University Press.

Búzás, Zoltán I. 2021. Racism and Antiracism in the Liberal International Order. International Organization 75 (2). <https://doi.org/10.1017/S0020818320000521>.

Búzás, Zoltán I. 2018. Is the Good News About Law Compliance Good News About Norm Compliance? The Case of Racial Equality. International Organization 72 (2):351-85.

Checkel, Jeffrey, 2001: Why Comply? Social Learning and European Identity Change. International Organization 55 (3):553-88.

Colgan, Jeff D., and Robert O. Keohane. 2017. The Liberal Order Is Rigged: Fix It Now or Watch It Wither. Foreign Affairs 96:36-44.

Cooley, Alexander, and Daniel H. Nexon. 2020. Exit from Hegemony: The Unraveling of the American Global Order. Oxford University Press.

Cramer, Katherine Walsh. 2016. The Politics of Resentment: Rural Consciousness in Wisconsin and the Rise of Scott Walker. University of Chicago Press.

Daddow, Oliver. 2012. The UK Media and "Europe": From Permissive Consensus to Destructive Dissent. International Affairs 88 (6):1219-36.

De Vries, Catherine, and Erica Edwards. 2009. Taking Europe to Its Extremes: Extremist Parties and Public Euroscepticism. Party Politics 15 (1):5-28. 
Drolet, Jean-François, and Michael C. Williams. 2018. Radical Conservatism and Global Order: International Theory and the New Right. International Theory 10 (3): 285-313.

Dunne, Tim, and Christian Reus-Smit. 2017. The Globalization of International Society. Oxford University Press.

Eichengreen, Barry, and David Leblang. 2008. Democracy and Globalization. Economics and Politics 20 (3):289-334.

Elias, Norbert, and J.L. Scotson. 1994 [1965]. The Established and Outsiders. Sage.

Ellinas, Antonis A. 2010. The Media and the Far Right in Western Europe: Playing the Nationalist Card. Cambridge University Press.

Epstein, Charlotte, Thomas Lindemann, and Ole Jacob Sending. 2018. Frustrated Sovereigns: The Agency that Makes the World Go Around. Review of International Studies 44 (5):787-804.

Fanon, Frantz. 1952. Peau noire, masques blancs. Éditions du Seuil.

Fearon, James D. 1994. Domestic Political Audiences and the Escalation of International Disputes. American Political Science Review 88 (3):577-92.

Finnemore, Martha, and Kathryn Sikkink. 1998. International Norm Dynamics and Political Change. International Organization 52 (4):887-917.

Fraser, Nancy, and Axel Honneth. 2003. Redistribution or Recognition? A Political-Philosophical Exchange. Verso.

Friedrichs, Jorg. 2016. An Intercultural Theory of International Relations: How Self-Worth Underlies Politics Among Nations. International Theory 8 (1):63-96.

Gallagher, Julia. 2018. Misrecognition in the Making of a State: Ghana's International Relations Under Kwame Nkrumah. Review of International Studies 44 (5):882-901.

Gallup. 1956. Mange er skeptiske, men flest uvidende om det arbejde FN har udført gennem årene. Dansk Gallup Institut.

Gallup. 1958. Hvordan befolkningen ser på vort internationale samarbejde. Dansk Gallup Institut.

Galston, William A., ed. 2018. Anti-Pluralism—The Populist Threat to Liberal Democracy. Yale University Press.

Gartman, David. 2004. Three Ages of the Automobile: The Cultural Logics of the Car. Theory, Culture and Society 21 (4-5):169-95.

Gehrke, Joel. 2019. State Department Preparing for Clash of Civilizations with China. Washington Examiner. 30 April Available at <https://www.washingtonexaminer.com/policy/defense-national-security/ state-department-preparing-for-clash-of-civilizations-with-china>. Accessed 10 May 2019.

Gest, Justin, Tyler Reny, and Jeremy Mayer. 2017. Roots of the Radical Right: Nostalgic Deprivation in the United States and Britain. Comparative Political Studies 51 (13):1694-719.

Gidron, Noam, and Peter A. Hall. 2017. The Politics of Social Status: Economic and Cultural Roots of the Populist Right. The British Journal of Sociology 68:S57-S84.

Gilman, Nils. 2018. Modernization Theory Never Dies. History of Political Economy 50 (S1):133-51.

Gilpin, Robert. 1981. War and Change in World Politics. Cambridge University Press.

Goddard, Stacie E. 2018. Embedded Revisionism: Networks, Institutions, and Challenges to World Order. International Organization 72 (4):763-97.

Goffman, Erving. 1956. The Presentation of Self in Everyday Life. Doubleday.

Goffman, Erving. 1963. Stigma: Notes on the Management of Spoiled Identity. Penguin.

Golovchenko, Yevgeniy, Mareike Hartmann, and Rebecca Adler-Nissen. 2018. State, Media and Civil Society in the Information Warfare over Ukraine: Citizen Curators of Digital Disinformation. International Affairs 94 (5):975-94.

Gong, Gerrit W. 1984. The Standard of "Civilization" in International Society. Oxford University Press. Goodwin, Matthew, and Oliver Heath. 2016. The 2016 Referendum, Brexit and the Left Behind: An Aggregate-level Analysis of the Result. The Political Quarterly 87 (3):323-32.

Gourevitch, Peter. 2002. Domestic Politics and International Relations. In Handbook of International Relations, edited by Walter Carlsnaes, Thomas Risse, and Beth A. Simmons, 309-28. Sage.

Grossman, Emiliano and Nicolas Sauger. 2019. Economic Internationalization and the Decline of the LeftRight Dimension. Party Politics 25 (1):36-49. 
Gutmann, Amy. 2003. Identity in Democracy. Princeton University Press.

Haas, Ernst B. 1970. Human Rights and International Action. Stanford University Press.

Hacker, Jacob S. 2006. The Great Risk Shift: The New Economic Insecurity and the Decline of the American Dream. Oxford University Press.

Hegel, Georg W.F. 1807. Phenomenology of Spirit. Translated by A.V. Miller. 1977. Oxford University Press.

Hendrickson, Clara. 2018. The European Project and Its Enemies. In Anti-Pluralism-The Populist Threat to Liberal Democracy, edited by William Galston, 41-63. Yale University Press.

Hjorth, Frederik, and Rebecca Adler-Nissen. 2019. Ideological Asymmetry in the Reach of Pro-Russian Digital Disinformation to United States Audiences. Journal of Communication 69 (2):168-92.

Hobolt, Sara B., and James Tilley 2014. Blaming Europe? Responsibility Without Accountability in the European Union. Oxford University Press.

Hobson, John M., and Jason C. Sharman. 2005. The Enduring Place of Hierarchy in World Politics: Tracing the Social Logics of Hierarchy and Political Change. European Journal of International Relations 11 (2):63-98.

Hochschild, Arlie Russell. 2016. Strangers in Their Own Land: Anger and Mourning on the American Right. The New Press.

Holm, Minda, and Ole Jacob Sending. 2018. Select States Before Relations: On Misrecognition and the Bifurcated Regime of Sovereignty. Review of International Studies 44 (5):829-47.

Holsti, Ole R. 1992. Public Opinion and Foreign Policy: Challenges to the Almond-Lippmann Consensus. International Studies Quarterly 36 (4):439-66.

Honneth, Axel. 2001. Recognition or Redistribution? Changing Perspectives on the Moral Order of Society. Theory, Culture and Society 18 (2-3):43-55.

Hooghe, Liesbet, and Gary Marks. 2009. A Postfunctionalist Theory of European Integration: From Permissive Consensus to Constraining Dissensus. British Journal of Political Science 39 (1):1-23.

Hooghe, Liesbet, Gary Marks, and Carole J. Wilson. 2002. Does Left/Right Structure Party Positions on European Integration? Comparative Political Studies 35 (8):965-89

Hoskins, Andrew, and Ben O'Loughlin. 2015. Arrested War: The Third Phase of Mediatization. Information, Communication and Society 18 (11):1320-38.

Ikenberry, John. 2001. American Power and the Empire of Capitalist Democracy. Review of International Studies 27 (5):191-212.

Ikenberry, John. 2011. Liberal Leviathan: The Origins, Crisis, and Transformation of the American World Order. Princeton University Press.

Ikenberry, John. 2018. The End of Liberal International Order? International Affairs 94 (1):17-23.

Ikenberry, John, and Daniel H. Nexon. 2019. Hegemony Studies 3.0: The Dynamics of Hegemonic Orders. Security Studies 28 (3):395-421

Inglehart, Ronald, and Pippa Norris. 2016. Trump, Brexit, and the Rise of Populism: Economic Have-Nots and Cultural Backlash. Working Paper No. RWP16-026, Harvard Kennedy School.

Jahn, Beate. 2018. Liberal Internationalism: Historical Trajectory and Current Prospects. International Affairs 94 (1):43-61.

Keck, Margaret E., and Kathryn Sikkink. 1998. Activists Beyond Borders: Advocacy Networks in International Politics. Cornell University Press.

Keene, Edward. 2002. Beyond the Anarchical Society: Grotius, Colonialism and Order in World Politics. Cambridge University Press.

Keohane, Robert O. 1984. After Hegemony: Cooperation and Discord in the World Political Economy. Princeton University Press.

Kimmel, Michael. 2017. Angry White Men: American Masculinity at the End of an Era. Bold Type Books.

Kinnvall, Catarina, and Ted Svensson. 2018. Misrecognition and the Indian state: the Desire for Sovereign Agency. Review of International Studies 44 (5):902-21.

Kirkpatrick, David D., Ben Hubbard, Mark Landler, and Mark Mazzetti. 2018. The Wooing of Jared Kushner: How the Saudis Got a Friend in the White House. New York Times, 8 December. Retrieved from <www.nytimes.com/2018/12/08/world/middleeast/saudi-mbs-jared-kushner.html>. Accessed 22 May 2019. 
Klapsis, Antonis. 2015. An Unholy Alliance: The European Far Right and Putin's Russia. Wilfried Martens Centre for European Studies.

Krastev, Ivan, and Stephen Holmes. 2019. The Light that Failed-A Reckoning. Penguin.

Kupchan, Charles A., and Peter L. Trubowitz. 2007. Grand Strategy for a Divided America. Foreign Affairs 86 (4):71-83.

Lake, David A. 1999. Entangling Relations: American Foreign Policy in Its Century. Princeton University Press.

Lake, David A. 2009. Hierarchy in International Relations. Cornell University Press.

Lake, David A. 2010. Making America Safe for the World: Multilateralism and the Rehabilitation of US Authority. Global Governance 16 (4):471-84.

Lake, David A., Lisa L. Martin, and Thomas Risse. 2021. Challenges to the Liberal Order: Reflections on International Organization. International Organization 75 (2). <https://doi.org/10.1017/ S0020818320000636>.

Lanoszka, Alexander. 2016. Russian Hybrid Warfare and Extended Deterrence in Eastern Europe. International Affairs 92 (1):175-95.

Laruelle, Marlene. 2018. Russian and American Far Right Connections: Confluence, Not Influence. PONARS Policy Memo no. 516, IERES, George Washington University.

Lawson, George. 2019. Anatomies of Revolution. Cambridge University Press.

Lebow, Richard Ned. 2008. Cultural Theory of International Relations. Cambridge University Press.

Lindberg, Leon N., and Stuart A. Scheingold. 1970. Europe's Would-Be Polity: Patterns of Change in the European Community. Prentice Hall.

Lindemann, Thomas. 2013. The Case for an Empirical and Social-Psychological Study of Recognition in International Relations. International Theory 5 (1):473-92.

Lindemann, Thomas, and Erik Ringmar, eds. 2014. The International Politics of Recognition. Paradigm.

Lukito, Josephine, Yini Zhang, Larissa Doroshenko, Sang Jung Kim, Min-Hsin Su, Yiping Xia, Deen Freelon, and Chris Wells. 2020. The Wolves in Sheep's Clothing: How Russia's Internet Research Agency Tweets Appeared in US News as Vox People. The International Journal of Press/Politics 25 (2):196-216.

Makarychev, Andrey. 2017. The Russian World, Post-Truth, and Europe. PONARS Policy Memo no. 477, IERES, George Washington University.

Mälksoo, Maria. 2009. The Memory Politics of Becoming European: The East European Subalterns and the Collective Memory of Europe. European Journal of International Relations 15 (4):653-80.

Mälksoo, Maria. 2010. The Politics of Becoming European: Security Imaginaries in Poland and the Baltic States. Routledge.

Manela, Erez. 2007. The Wilsonian Moment: Self-Determination and the International Origins of Anticolonial Nationalism. Oxford University Press.

Mann, Michael. 2007. Predation and Production. In Ernest Gellner and Contemporary Social Thought, edited by Siniša Maleševic and Mark Haugaard, 50-74. Cambridge University Press.

Marinov, Nikolay, and Hein Goemans. 2013. Coups and Democracy. British Journal of Political Science 44 (4):799-825.

Markell, Patchen. 2003. Bound by Recognition. Princeton University Press.

Martin, Lisa L. 2000. Democratic Commitments: Legislatures and International Cooperation. Princeton University Press.

Martin, Lisa L., and Beth A. Simmons. 1998. Theories and Empirical Studies of International Institutions. International Organization 52 (4):729-57.

Mazower, Mark. 2013. Governing the World: The History of an Idea, 1815 to the Present. Penguin.

McCargo, Duncan, and Ayşe Zarakol. 2012. Turkey and Thailand: Unlikely Twins. Journal of Democracy 23 (3):71-79.

McDermott, Rose, and Peter K. Hatemi. 2018. To Go Forward, We Must Look Back: The Importance of Evolutionary Psychology for Understanding Modern Politics. Evolutionary Psychology 16 (2):1-7.

Mead, Walter R. 2011. The Tea Party and American Foreign Policy: What Populism Means for Globalism. Foreign Affairs 90 (2):28-44. 
Morefield, Jeanne. 2005. Covenants Without Swords: Idealist Liberalism and the Spirit of Empire. Princeton University Press.

Morefield, Jeanne. 2014. Empires Without Imperialism. Oxford University Press.

Mudde, Cas. 2004. The Populist Zeitgeist. Government and Opposition 39 (4):541-63.

Mudde, Cas. 2016. Europe's Populist Surge. Foreign Affairs 95 (6):25-30.

Muis, Jasper, and Tim Immerzeel. 2017. Causes and Consequences of the Rise of Populist Radical Right Parties and Movements in Europe. Current Sociology 65 (6):909-30.

Mutz, Diana C. 2018. Status Threat, Not Economic Hardship, Explains the 2016 Presidential Vote. PNAS. 115 (19):E4330-39.

Naylor, Tristen. 2018. Social Closure and International Society: Status Groups from the Family of Civilised Nations to the G20. Routledge.

Neumann, Iver. 1995. Russia and the Idea of Europe. Routledge.

Neumann, Iver. 1998. Uses of the Other. University of Minnesota Press.

Nye, Joseph. 2017. Will the Liberal Order Survive? The History of an Idea. Foreign Affairs 96 (1):10-16

Osterhammel, Jürgen. 2015. The Transformation of the World: A Global History of the Nineteenth Century. Princeton University Press.

Pepinsky, Thomas. 2017. Dis-embedding Liberal Internationalism. Available at $<\mathrm{http}: / / \mathrm{dx}$.doi.org/10.2139/ ssrn.3054001>. Accessed 22 May 2019.

Pevehouse, Jon. 2002. Democracy from the Outside-in? International Organizations and Democratization. International Organization 56 (3):515-49.

Pew Research Center. 2017. Public Trust in Government 1958-2017. Available at <http://www.peoplepress.org/2017/12/14/public-trust-in-government-1958-2017/>. Accessed 11 September 2020.

Phillips, Tom. 2018. Trump of the Tropics: The "Dangerous" Candidate Leading Brazil's Presidential Race. The Guardian, 19 April. Available at <https://www.theguardian.com/world/2018/apr/19/jairbolsonaro-brazil-presidential-candidate-trump-parallels>. Accessed 19 May 2019.

Pomerantsev, Peter. 2015. Authoritarianism Goes Global (II): The Kremlin's Information War. Journal of Democracy 26 (4):40-50.

Pomeranz, Keith. 2009. The Great Divergence: China, Europe, and the Making of the Modern World Economy. Princeton University Press.

Pouliot, Vincent. 2016. International Pecking Orders: The Politics and Practice of Multilateral Diplomacy. Cambridge University Press.

Rathbun, Brian, Joshua D. Kertzer, Jason Reifler, Paul Goren, and Thomas J. Scotto. 2016. Taking Foreign Policy Personally: Personal Values and Foreign Policy Attitudes. International Studies Quarterly 60 (1): 124-37.

Rejai, Mostafa, ed. 2017. Ideology: Comparative and Cultural Status. Routledge.

Reus-Smit, Christian. 2013. Individual Rights and the Making of the International System. Cambridge University Press.

Reus-Smit, Christian. 2017. Cultural Diversity and International Order. International Organization 71 (4): $851-85$.

Ringmar, Erik. 2002. The Recognition Game: Soviet Russia Against the West. Cooperation and Conflict 37 (2):115-136.

Ringmar, Erik. 2014. Recognition and the Origins of International Society. Global Discourse 4 (4):446-58.

Rooduijn, Matthijs, Wouter Van Der Brug, and Sarah L. De Lange. 2016. Expressing or Fuelling Discontent? The Relationship Between Populist Voting and Political Discontent. Electoral Studies 43 (1):32-40.

Rumelili, Bahar 2008. Negotiating Europe: EU-Turkey Relations from an Identity Perspective. Insight Turkey 10 (1):97-110.

Rydgren, Jens. 2005. Is Extreme Right-Wing Populism Contagious? Explaining the Emergence of a New Party Family. European Journal of Political Research 44 (3):413-37.

Schlipphak, Bernd, and Oliver Treib. 2017. Playing the Blame Game on Brussels: The Domestic Political Effects of EU Interventions Against Democratic Backsliding. Journal of European Public Policy 24 (3): $352-65$. 
Schmitt, Olivier. 2020. How to Challenge an International Order: Russian Diplomatic Practices in Multilateral Security Organisations. European Journal of International Relations 26 (3):922-46

Shekhovtsov, Anton. 2018. Russia and the Western Far Right. Routledge.

Simmons, Beth A. 2009. Mobilizing for Human Rights: International Law in Domestic Politics. Cambridge University Press.

Singer, Jane B. 2014. User-Generated Visibility: Secondary Gatekeeping in a Shared Media Space. New Media and Society 16 (1):55-73.

Smith, Tom W., and Lars Jarkko. 1998. National Pride: A Cross-National Analysis. National Opinion Research Center. University of Chicago.

Spruyt, Bram, Gil Keppens, and Filip Van Droogenbroeck. 2016. Who Supports Populism and What Attracts People to It? Political Research Quarterly 69 (2):335-46.

Sternhell, Zev. 2019. Why Benjamin Netanyahu Loves the European Far-Right. Foreign Policy, 24 February. Available at <https://foreignpolicy.com/2019/02/24/why-benjamin-netanyahu-loves-theeuropean-far-right-orban-kaczynski-pis-fidesz-visegrad-likud-antisemitism-hungary-poland-illiberalism/> . Accessed 19 May 2019.

Strömbom, Lisa. 2014. Thick Recognition: Advancing Theory on Identity Change in Intractable Conflicts. European Journal of International Relations 20 (1):168-91.

Stukal, Denis, Sergey Sanovich, Richard Bonneau, and Joshua A. Tucker. 2017. Detecting Bots on Russian Political Twitter. Big Data 5 (4):310-24.

Subotic, Jelena. 2011. Europe Is a State of Mind: Identity and Europeanization in the Balkans. International Studies Quarterly 55 (2):309-30.

Suzuki, Shogo. 2017. "Delinquent Gangs" in the International System Hierarchy. In Hierarchies in World Politics, edited by Ayşe Zarakol, 219-40. Cambridge University Press.

Taylor, Charles. 1992. Multiculturalism and The Politics of Recognition. Princeton University Press.

Tjalve, Vibeke Schou, ed. 2020. Geopolitical Amnesia: The Rise of the Right and the Crisis of Liberal Memory. McGill-Queen's University Press.

Tooze, Adam. 2018. Crashed: How a Decade of Financial Crises Changed the World. Penguin.

Towns, Ann. 2010. Women and States: Norms and Hierarchies in International Society. Cambridge University Press.

Towns, Ann, and Bahar Rumelili. 2017. Taking the Pressure: Unpacking the Relation Between Norms, Social Hierarchies, and Social Pressures on States. European Journal of International Relations 23 (4):756-79.

Tsygankov, Andrei P. 2012. Russia and the West from Alexander to Putin: Honor in International Relations. Cambridge University Press.

Ünver, Akin. 2019. Russian Digital Media and Information Ecosystem in Turkey. Edam Cyber Governance and Digital Democracy Report.

Viola, Lora Anne. 2020. The Closure of the International System. Cambridge University Press.

Ward, Steven. 2017. Status and the Challenge of Rising Powers. Cambridge University Press.

Way, Lucan, and Adam Casey. 2018. Russian Foreign Election Interventions Since 1991. PONARS Policy Memo No. 520, George Washington University.

Wendt, Alexander. 1999. Social Theory of International Relations. Cambridge University Press.

Wiener, Antje. 2018. Contestation and the Constitution of Norms in Global International Relations. Oxford University Press.

Wittkopf, Eugene R. 1990. Faces of Internationalism: Public Opinion and American Foreign Policy. Duke University Press.

Wohlforth, William C., Benjamin de Carvalho, Halvard Leira, and Iver B. Neumann. 2017. Moral Authority and Status in International Relations: Good States and the Social Dimension of Status Seeking. Review of International Studies 44 (3):526-46.

Wolf, Reinhard. 2011. Respect and Disrespect in International Politics: The Significance of Status Recognition. International Theory 3 (1):105-42. 
Zaborowski, Marcin. 2006. Westernizing the East: External Influences in the Post-communist Transformation of Eastern and Central Europe. Journal of Communist Studies and Transition Politics 21 (1):16-32.

Zarakol, Ayşe. 2010. Ontological Insecurity and State Denial of Historical Crimes: Turkey and Japan. International Relations 24 (1):3-23.

Zarakol, Ayşe. 2011. After Defeat: How the East Learned to Live with the West. Cambridge University Press.

Zarakol, Ayşe. 2013. Revisiting Second Image Reversed: Lessons from Turkey and Thailand. International Studies Quarterly 50 (1):150-62.

Zarakol, Ayşe. 2014. What Made the Modern World Hang Together: Socialisation or Stigmatization? International Theory 6 (2):311-32.

Zarakol, Ayşe. 2017a. Hierarchies in World Politics. Cambridge University Press.

Zarakol, Ayşe. 2017b. Theorising Hierarchies. In Hierarchies in World Politics, edited by Ayşe Zarakol, 1-14. Cambridge University Press.

Zarakol, Ayşe. 2018. Sovereign Equality as Misrecognition. Review of International Studies 44 (5):848-62. Zarakol, Ayşe. 2019. Rise of the Rest: As Hype and Reality. International Relations. 33 (2):213-28.

\section{Authors}

Rebecca Adler-Nissen is Professor of Political Science at the University of Copenhagen. She can be reached atran@ifs.ku.dk.

Ayşe Zarakol is Reader in International Relations at the University of Cambridge. She can be reached at az319@cam.ac.uk.

\section{Acknowledgments}

Earlier versions of this article were presented at seminars at the Free University of Berlin, the London School of Economics, the University of Bath, the University of Copenhagen, the University of Madison, the University of Minnesota, Oxford University, Victoria University of Wellington, and the School of Global Studies, University of Gothenburg. We thank those who were present on those occasions for their criticisms, questions, and suggestions. We are particularly grateful to the following for their feedback: the special issue editors (David Lake, Lisa Martin, and Thomas Risse), Emanuel Adler, Michael Barnett, Andre Barrinha, Alexander Bukh, Raymond Duvall, Kristin Eggeling, Tanisha Fazal, Yevgeniy Golovchenko, Lene Hansen, Frederik Hjorth, Andy Hurell, Peter Katzenstein, Ron Krebs, Chris ReusSmit, Karen Gram Skjoldager, Patrice Wangen, Erik Voeten, Ole Wæver, and Michael Zürn. We also thank our students and Zoe Burke, Yi Ning Chang, Viktor Emil Madsen, and Frederik Windfeld for research assistance.

\section{Funding}

Our research has been supported by the European Research Council; grant number 680102 (DIPLOFACE).

\section{Key Words}

Hierarchy; Liberal International Order; populism; recognition; Russia; status; the West

Date received: October 12, 2019; Date accepted: June 30, 2020 